\title{
Penentuan Persyaratan Teknik dari Mesin Pemutar Adonan Es, Menggunakan QFD Fase Pertama
}

\author{
Determination of Technical Requirement of Centrifuge Dough Machine, \\ Using the First Phase QFD
}

\author{
Abiyy u Satria wan, Yus wono Hadi \\ Universitas Ma Chung, Malang \\ E-mail: $411210001 @$ student.machung.ac.id
}

\begin{abstract}
Abstrak
UMKM (Usaha Mikro, Kecil, dan Menengah) XYZ merupakan salah satu produsen es puter, yang mana proses produksinya masih dilakukan secara manual. Salah proses porduksinya adalah proses proses pemutaran adonan es yang memerlukan waktu sekitar 2,5 jam. Hal ini tentu sangat tidak efisien, boros waktu, dan membutuhkan tenaga yang besar. Resiko lainnya adalah pekerja menjadi cepat lelah sehingga dapat menimbulkan kesalahan dalam proses produksi dan mengakibatkan kerugian. Keberadaan mesin pemutar adonan es tentu akan sangat membantu para produsen es puter. Pada penelitian ini, pendekatan dilakukan dengan Metode QFD sehingga dapat memahami kebutuhan alat bantu atau mesin yang digunakan pada proses pemutaran adonan es. Metode QFD yang digunakan adalah QFD fase pertama yakni perencanaan produk atau matriks HOQ (House of Quality). Hasil dari pendekatan menggunakan metode QFD adalah atribut-atribut yang dapat digunakan sebagai dasar dalam melakukan rancang bangun mesin pemutar adonan es. Penyusunan QFD fase pertama atau matriks HOQ (House of Quality) mendapatkan sembilan atribut kebutuhan konsumen. Atribut kebutuhan konsumen yang didapatkan antara lain: mesin tidak mudah panas, kecepatan putaran dapat diatur sesuai kebutuhan, dapat memutar 2 tabung sekaligus, mesin mudah dibersihkan, tabung es mudah dimasukkan dan dikeluarkan dari mesin, mesin menggunakan material yang kuat dan kokoh, mesin mudah diperbaiki, mesin tidak makan tempat, dan mesin mudah dibuat. Berdasarkan diskusi dengan narasumber ahli, didapatkan sepuluh atribut persyaratan teknik. Atribut persyaratan teknik tersebut antara lain: mesin listrik, kecepatan putaran, diameter pulley, belt pemutar, desain modular, alas mesin, jenis material, jenis pengunci, dimensi mesin, serta bentuk rangka mesin.
\end{abstract}

Kata kunci: QFD, QFD fase pertama, atribut kebutuhan konsumen, persyaratan teknis

\begin{abstract}
SMEs (Small to Medium Enterprise) XYZ is one manufacturer of swivel ice, where the production process is still done manually. One of the production process is spin the dough which takes about 2.5 hours. This is very inefficient, time consuming, and requires a large force. Another risk is the workers become tired quickly so that it can lead to errors in the production process and resulting in losses. The existence of centrifuges dough machine will greatly help swivel ice manufacturers. In this study, to understand the needs for tools or machines used in the spinning dough process using QFD method approach. There are two phase of QFD that used in this study, first phase of QFD is product planning or matrix HOQ (House of Quality), and the second phase of the QFD is product design. The results of the approach of using QFD are attributes that can be used as a basis for design of centrifuges dough machine. There are nine attributes identified as consumer needs (voice of the customer). Attributes the needs of consumer that obtained is: the machine is not easy to heat, the rotation speed can be adjusted as needed, can play two tubes at once, the machine easy to clean, tube ice easily inserted and removed from the machine, using a material that is strong and sturdy, the machine easily repaired, the machine not need a large space, and the machine is easy to made. After identifying the needs of consumers, the preparation of the first phase of QFD can begin. The results of the first phase of the preparation of QFD, obtained ten attributes of technical requirements. Attributes technical requirements is: electrical machinery, the speed of rotation, diameter pulley, belt players, modular design, ironing machine, material type, the type of lock, the dimensions of the machine, as well as the shape of the machine frame.

Keywords: QFD, first phase of QFD, voice of customer, technical requirement
\end{abstract}




\section{Pendahuluan}

Teknologi dan ilmu pengetahuan pada masa kini berkembang sangat pesat, hal tersebut tentu mempengaruhi berbagai bidang dalam kehidupan sehari-hari. Pemanfaatan teknologi dalam suatu proses bisnis digunakan untuk pemasaran, keuangan, maupun dalam hal produksi. Penggunaan teknologi yang lebih modern membuat pelaku usaha dapat menghasilkan jumlah produk yang lebih besar (sesuai kapasitas mesin), dalam waktu yang lebih singkat dan penggunaan tenaga kerja yang lebih sedikit daripada dengan cara tradisional atau manual.

UMKM XYZ merupakan salah satu produsen es puter, yang mana proses produksinya masih dilakukan secara manual. Salah proses porduksinya adalah proses proses pemutaran adonan es yang memerlukan waktu sekitar 2,5 jam. Hal ini tentu sangat tidak efisien, boros waktu, dan membutuhkan tenaga yang besar. Resiko lainnya adalah pekerja menjadi cepat lelah sehingga dapat menimbulkan kesalahan dalam proses produksi dan mengakibatkan kerugian. Keberadaan mesin pemutar adonan es tentu akan sangat membantu para produsen es puter. Manfaat yang dapat dirasakan adalah efisiensi dan proses produksi yang optimal. Selain proses produksi yang lebih efisien, tentu juga memperhatikan kualitas dari produk yang dihasilkan yakni es puter.

Pada penelitian ini, pendekatan dilakukan dengan Metode QFD sehingga dapat memahami kebutuhan a lat bantu atau mesin yang digunakan pada proses pemutaran adonan es. Metode QFD yang digunakan ada lah QFD fase pertama yakni perencanaan produk atau matriks HOQ (House of Quality). Hasil dari pendekatan menggunakan metode QFD adalah atribut-atribut yang dapat digunakan sebagai dasar dalam melakukan rancang bangun mesin pemutar adonan es.

\section{Tinjauan Pustaka}

Quality Funtion Deployment (QFD) pertama kali diperkenalkan oleh Yoji Akao dan Shigeru Mizuno sekitar tahun 1960-an di Jepang. Awalnya metode ini dikembangkan oleh Mitsubishi`s Kobe Shipyard, selanjutnya diadopsi oleh Toyota. Metode QFD dikembangkan sebagai penghubung antara konsumen dan perusahaan. Metode QFD juga merupakan sistem untuk mendesain suatu produk atau jasa berdasarkan permintaan konsumen, sebuah sistem dengan teratur yang mengubah kebutuhan konsumen menjadi spesifikasi produk maupun jasa (Pyzdek, 2003:121). Tujuan dari QFD adalah menerjemahkan kebutuhan konsumen kedalam karakteristik produk, sehingga dapat mencapai tingkat kepuasan konsumen (Bernal, dkk., 2014).

Terdapat beberapa manfaat dari penggunaan QFD yakni, dapat digunakan untuk membuat skala prioritas spesifikasi produk agar sesuai dengan kebutuhan konsumen dengan memperhatikan kompetitor. Metode QFD juga dapat digunakan untuk menemukan sisi kompetitif produk yang dapat dikembangkan. Selain itu, dengan menggunakan metode QFD juga dapat mempersingkat waktu yang diperlukan untuk pengembangan produk (Rahmatika, 2008). QFD juga dapat digunakan untuk memprioritaskan poin-poin penting yang berpotensi untuk ditingkatkan berdasarkan permintaan dan kebutuhan konsumen (Gargione, 1999). QFD sendiri memiliki beberapa kelemahan ketika akan digunakan (Jaiswal, 2012). QFD merupakan metode yang bersifat kualitatif, hal ini dikarenakan perbedaan kebutuhan dan keinginan masing-masing konsumen. Selain itu kebutuhan konsumen terkadang bersifat ambigu, dan sulit untuk dikategorikan sebagai permintaan.

Metode QFD terbagi atas empat fase yakni perencanaan produk (product planning), desain produk (product design), perencanaan proses (process planning), dan perencaan produksi (control planning) (Cohen, 1995). 


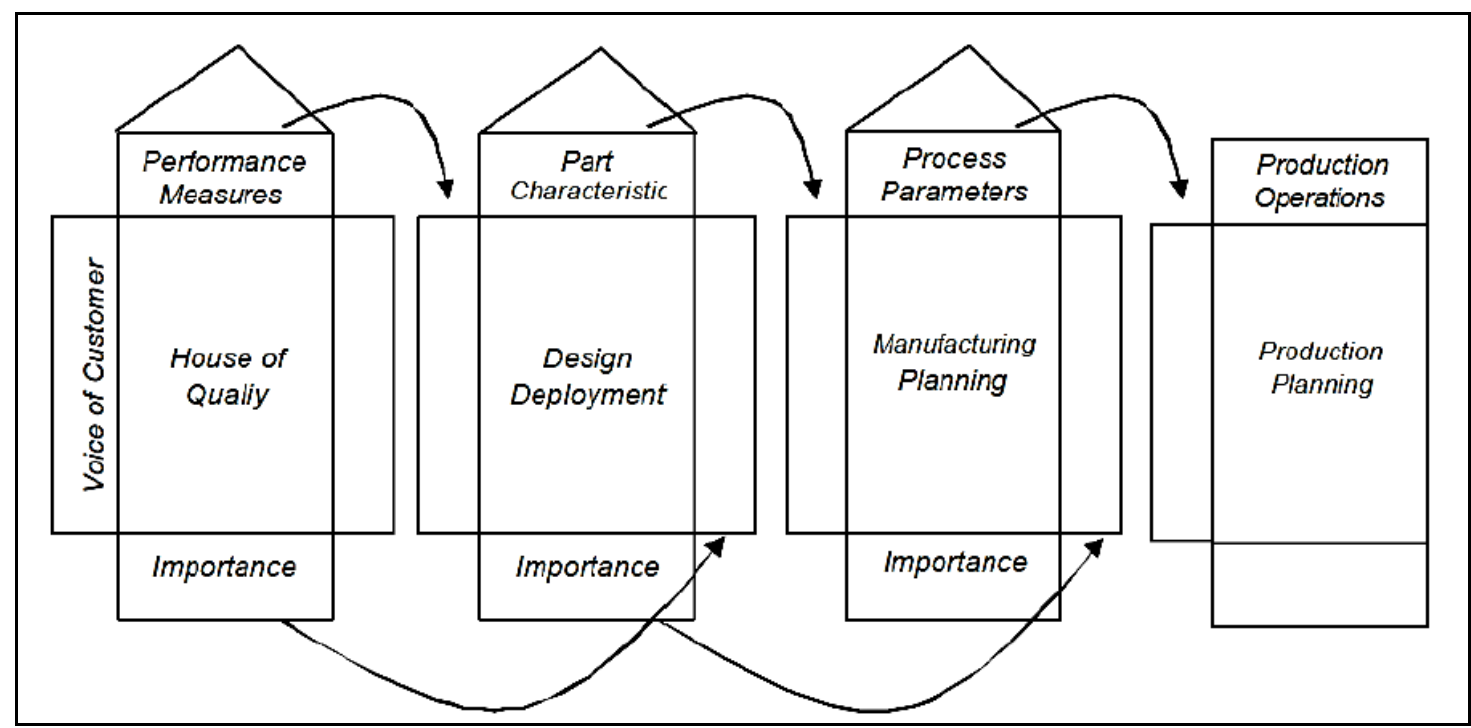

Gambar 1. Empat Fase dalam QFD (Cohen, 1995)

Fase pertama adalah fase perencanaan produk (product Planning), yang lebih dikenal sebagai rumah pertama (R1). Pada tahap ini dilakukan penggalian informasi mengenai kebutuhan konsumen. Setelah itu dilakukan proses penerjemahan kebutuhan konsumen tersebut kedalam sebuah karakteristik produk. Proses penerjemahan tersebut menggunakan matriks yang biasa disebut dengan house of quality (HOQ). Fase kedua adalah fase desain produk (product design), yang lebih dikenal sebagai rumah kedua (R2). Fase ini merupakan proses identifikasi dan penerjemahan desain kritis dalam pengembangan karakteristik produk. Fase ketiga adalah fase perencanaan proses (process planning), yang lebih dikenal sebagai rumah ketiga (R3). Fase ini digunakan untuk mengidentifikasi pengembangan proses pembuatan suatu produk. Pada tahap ini akan dihasilkan diagram dari suatu proses beserta critical process plan. Fase keempat adalah fase perencanaan produk (product Planning), yang lebih dikenal sebagai rumah keempat (R4). Fase ini bertujuan pada pengendalian dari suatu proses produksi, sehingga menghasilkan suatu prosedurprosedur pelaksanaan proses produksi.

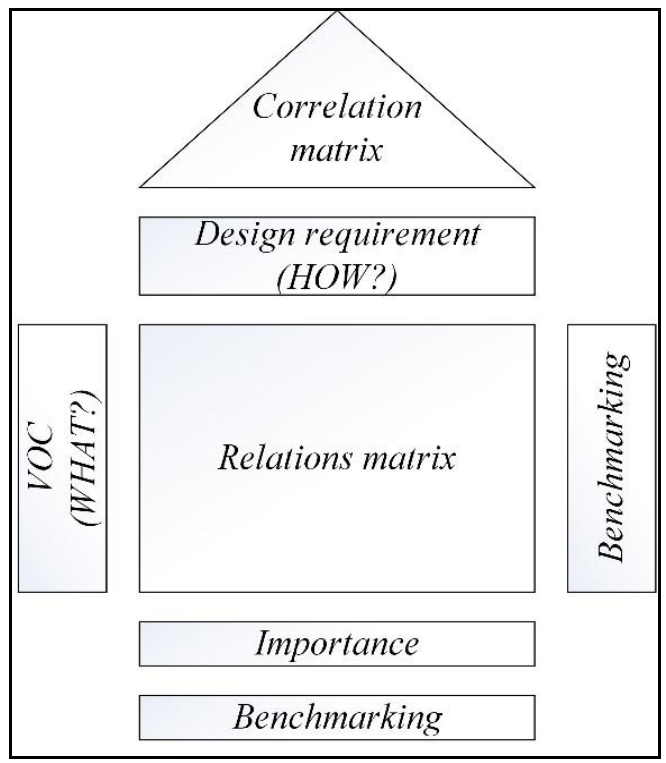

Gambar 2. House of Quality (HOQ) (Bernal, dkk., 2014)

House of Quality (HOQ) merupakan matrik kompleks yang merupakan salah satu bagian dalam menerjemahkan kebutuhan konsumen kedalam karakteristik produk ataupun jasa. Ide dari metode 
ini tidak hanya digunakan untuk menerjemahkan kebutuhan konsumen kedalam karakterisitik produk, namun juga memberikan prioritas untuk meningkatkan karakteristik tertentu (Van de poel, 2007). HOQ terbagi menjadi 7 bagian, seperti pada gambar 2. Ilustrasi gambar HOQ diatas bisa saja berbeda satu sama lain, mengenai tempat peletakannya. Namun penyusunan HOQ memiliki langkah sama yang teratur. Langkah-langkah dalam menyusun HOQ adalah sebagai berikut (Halim, 2014):

1. Matriks kebutuhan konsumen (Voice of Customer/VOC), merupakan keinginan ataupun kebutuhan konsumen dari suatu produk ataupun jasa yang ditawarkan.

2. Tingkat Kepentingan Konsumen (TKK), merupakan hasil penilaian konsumen mengenai matriks kebutuhan konsumen. Hasil penilaian ini didapatkan dari hasil kuisioner yang dibagikan, kemudian dilakukan pengolahan dan perhitungan data. Rumus yang digunakan untuk menghitung TKK adalah sebagai berikut:

$T K K=\frac{\sum x}{N}$

Dimana $\sum \mathrm{x}$ adalah total skor kepentingan, dan $\mathrm{N}$ merupakan jumlah responden

3. Tingkat Kepuasan Konsumen (TKP), merupakan penilaian kepuasan konsumen terhadap produk yang dibuat. Perhitungan dilakukan dengan cara memberikan nilai tingkat kepuasan terhadap atribut pada matriks kebutuhan konsumen. Rumus yang digunakan sama dengan rumus pada perhitungan TKK.

4. Perbandingan dengan kompetitor, merupakan hasil perbandingan antar produk yang dibuat dengan produk milik kompetitor. Hal ini dilakukan untuk mengetahui posisi produk yang dibuat terhadap pasar yang dituju. Perbandingan dapat dilakukan dengan melakukan benchmarking maupun hasil kuisioner.

5. Penentuan Target, merupakan acuan apakah atribut yang berada di matriks kebutuhan konsumen perlu perbaikan kualitas atau tidak. Nilai target didapatkan dari nilai tertinggi antara TKK dan TKP.

6. Rasio Perbaikan (Improvement Ration/IR), merupakan perbandingan antara target yang hendak dicapai dengan TKP. Rumus yang digunakan adalah:

$I R=\frac{\text { Target }}{\text { TKP }}$

7. Poin Penjualan (Sales Point), merupakan skala yang menunjukkan pengaruh atribut pada matriks kebutuhan konsumen dengan minat konsumen membeli produk. Apabila atribut tidak memengaruhi minat konsumen membeli produk maka bernilai 1 . Selanjutnya jika atribut memengaruhi minat konsumen untuk membeli produk bernilai 1,2, sedangkan jika sangat mempengaruhi bernilai 1,5 .

8. Raw Weight, merupakan pembobotan dari atribut yang terdapat pada matriks kebutuhan konsumen. Rumus dari raw weight adalah:

Raw Weight $=$ TKK $\times$ IR $\times$ Sales Point

9. Normalize Raw Weight, merupakan persentase pembobotan dari atribut yang terdapat pada matriks kebutuhan konsumen. Secara sederhana merupakan persentase raw weight dari jumlah totalnya. Rumus yang digunakan adalah:

Normalize $=\frac{\text { Raw Weight }}{\sum \text { Raw Weight }}$

10.Design Requirement (Persyaratan teknis/desain), merupakan atribut yang menggambarkan desain dari kebutuhan para konsumen pada suatu produk. Hal tersebut memunculkan suatu parameter penilaian dari kebutuhan konsumen tersebut. Matriks persyaratan teknis didapatkan dengan wawancara terhadap orang yang ahli ataupun mencari referensi dan studi kepustakaan

11. Matriks Relasi, merupakan matriks yang menunjukkan hubungan antara matriks persyaratan teknis dengan matriks kebutuhan konsumen. Relasi kedua matriks tersebut biasanya dinyatakan dengan simbol atau angka tertentu. 
Tabel 1. Contoh Simbol Relasi

\begin{tabular}{|ll|}
\hline & QFD 1 \\
\hline$\odot$ & 9 Strong Correlation \\
$\mathrm{o}$ & 3 Some Correlation \\
$\Delta$ & 1 Possible Correlation \\
- & 0 (Possible Negative Relation $)$ \\
\hline
\end{tabular}

12. Matriks Korelasi/Matriks Trade Off, merupakan matriks yang digunakan untuk menyatakan hubungan antar atribut pada matriks persyaratan teknis. Matriks ini berada diatas dan menyerupai atap rumah. Hubungan antara atribut tersebut bisa dinyatakan dengan angka maupun simbol tertentu.

13. Prioritas Matriks persyaratan teknis/Persyaratan Teknis, merupakan hasil perhitungan dari nilai pada matriks korelasi dengan nilai normalize raw weight. Rumus yang digunakan adalah:!

$$
\text { Prioritas } \left.=\sum \text { (Nilai matriks korelasi } x \text { normalize }\right)
$$

14. Kontribusi, menunjukkan persentase nilai prioritas suatu atribut matriks persyaratan teknis dari total jumlahnya. Rumus yang digunakan adalah:

$$
\text { Kontribusi }=\frac{\text { Prioritas }}{\sum \text { Prioritas }}
$$

15. Urutan Prioritas, merupakan urutan nilai prioritas mulai dari yang tertinggi hingga nilai prioritas terendah

Pada penelitian ini teknik pengambilan sampel yang digunakan adalah purposive atau judgemental sampling. Purposive sampling merupakan pengambilan sampel tertentu yang secara sengaja sesuai dengan persyaratan tertentu. Sehingga dapat dikatakan bahwa pengambilan sampel ini tidak acak, namun dipilih secara sengaja. Penggunaan teknik ini dilakukan karena adanya batasan-batasan yang menyulitkan ketikan akan menggunakan sampel acak (Ulwan, 2014). Jumlah sampel yang harus diambil dalam menggunakan teknik ini tidak ada angka pastinya. Pengambilan sampel dihentikan apabila data sudah dirasa cukup ataupun sudah dapat mencerminkan keadaan populasi.

\section{Metode Penelitian}

Berikut merupakan diagram alir dari penelitian yang digunakan:

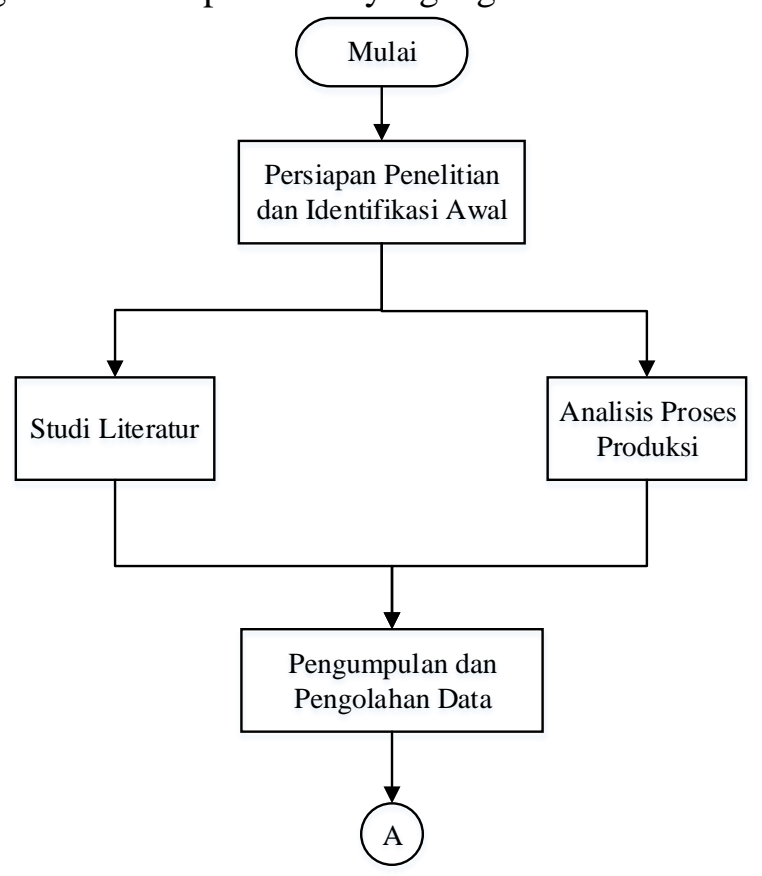

Gambar 3. Diagram Alir Penelitian 


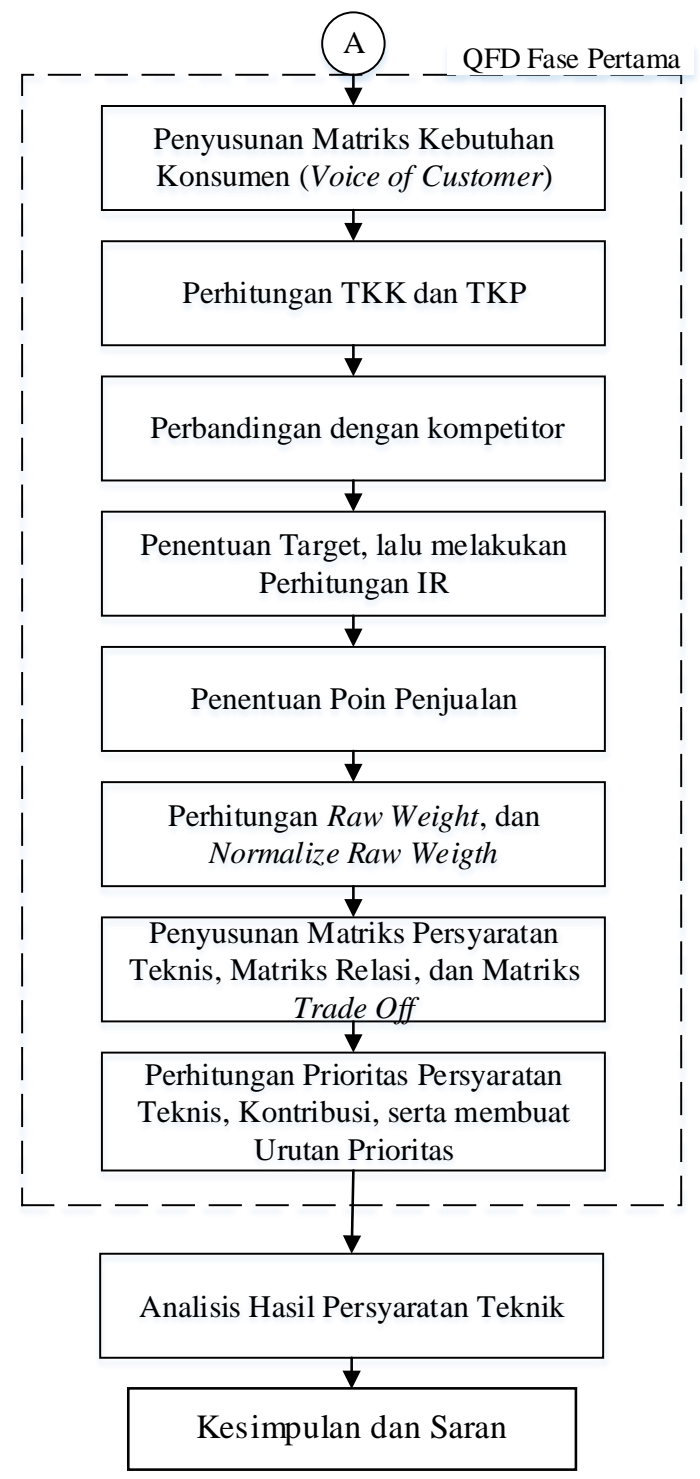

Gambar 3. Diagram Alir Penelitian (lanjutan)

\subsection{Persiapan Penelitian dan Identifikasi A wal}

Persiapan penelitian dan Identifikasi Awal dilakukan untuk mengetahui permasalahan yang dialami oleh UMKM XYZ. Pada tahap ini juga dilakukan perumusan masalah, penentuan mekanisme pengambilan data. Tahap ini juga termasuk menentukan kriteria responden yang akan diwawancara/mengisi kuisioner, menyusun daftar pertanyaan, dan jumlah responden yang akan digunakan.

\subsection{Studi Literatur}

Studi literatur dilakukan dengan cara mengumpulkan literatur yang digunakan seperti: buku, jurnal penelitian, dan sumber informasi lainnya yang relevan. Teori - teori yang dipelajari mengenai: perancangan, QFD (Quality Function Deployment) baik fase pertama dan fase kedua.

\subsection{Analis is Proses Produksi}

Pada tahap ini dilakukan observasi dari proses produksi pembuatan es puter yang dilakukan di UMKM XYZ. Obesravsi ini bertujuan untuk mengetahui langkah-langkah dalam proses produksi, bahan baku serta metode yang digunakan, dan waktu yang diperlukan dalam produksi es puter. Selain itu obeservasi dilakukan untuk mengetahui secara detail mengenai permasalahan yang dialami oleh UMKM XYZ. 


\subsection{Pengumpulan dan Pengolahan Data}

Pada tahap ini akan dilakukan wawancara dan penyebaran kuisioner untuk menyusun QFD fase pertama. Kuisioner pada QFD fase pertama dilakukan untuk menyusun matriks kebutuhan konsumen, mengetahui tingkat kepentingan konsumen, mengetahui tingkat kepuasan konsumen, serta mengetahui poin penjualan dari produk.

\subsection{Penyusunan Matriks Ke butuhan Kons umen (Voice of Customer)}

Pada tahap ini dilakukan identifikasi kebutuhan konsumen mengenai mesin pemutar es. Identifikasi kebutuhan konsumen dilakukan dengan melakukan wawancara terhadap responden yang telah ditentukan.

\subsection{Perhitungan TKK dan TKP}

Perhitungan TKK (Tingkat Kepentingan Konsumen) dilakukan untuk mengetahui penilaian konsumen terhadap setiap atribut pada matriks kebutuhan konsumen. Penilaian ini dilakukan untuk mengetahui atribut yang dirasa penting oleh konsumen. Setelah melakukan penilaian dan perhitungan TKK, selanjunya adalah melakukan penilaian dan perhitungan TKP (Tingkat Kepuasan Konsumen). Penilaian ini dilakukan untuk mengetahui tingkat kepuasan konsumen terhadap produk yang telah ditentukan.

\subsection{Perbandingan dengan Kompetitor}

Perbandingan dengan kompetitor dilakukan untuk mengetahui posisi produk dengan kompetitor. Perbandingan ini juga dilakukan untuk membandingkan kelemahan dan kelebihan produk dengan kompetitor.

\subsection{Penentuan Target, lalu Melakukan Perhitungan IR}

Target merupakan acuan apakah atribut pada matriks kebutuhan konsumen perlu perbaikan kualitas atau tidak. Penilaian target didapatkan dari nilai tertinggi antara TKK dan TKP. Setelah penentuan target, maka dilakukan penilaian IR (Improvement Ratio). IR didapatkan dari perbandingan antara target dan TKP. Apabila nilai IR > 1, maka atribut tersebut perlu dilakukan perbaikan.

\subsection{Penentuan Poin Penjualan}

Penentuan poin penjualan dilakukan untuk mengetahui pengaruh atribut pada matriks kebutuhan konsumen terhadap minat konsumen membeli produk. penentuan poin penjualan dilakukan dengan cara pengisian kuisioner oleh responden, dan memberikan penilaian terhadap setiap atribut yang ada pada matriks kebutuhan konsumen. Rentang penilaian dibagi menjadi tiga kaetgori, yakni: 1, 1.2, dan 1.5. Apabila atribut tidak memengaruhi minat konsumen membeli produk maka bernilai 1. Selanjutnya jika atribut memengaruhi minat konsumen untuk membeli produk bernilai 1,2, sedangkan jika sangat mempengaruhi bernilai 1,5.

\subsection{Perhitungan Raw Weight, dan Normmalize Raw Weight}

Pada tahap ini dilakukan perhitungan Raw Weight, dan Normmalize Raw Weight dari setiap atribut pada matriks kebutuhan konsumen. Perhitungan dilakukan dengan menggunakan rumus 3 dan 4 .

\subsection{Penyusunan Matriks Pers yaratan Teknis, Matriks Relasi, dan Matriks Trade Off}

Pada tahap ini dilakukan penyusunan matriks persyaratan teknis, dimana merupakan penerjemahan dari atribut pada matriks kebutuhan konsumen menjadi persyaratan teknis suatu produk. Penyusunan matriks persyaratan konsumen dilakukan dengan melakukan wawancara kepada narasumber ahli. Setelah menyusun matriks persyaratan teknis, matriks relasi dan matriks trade off dapat dibuat. Matriks relasi menunjukkan hubungan antara matriks persyaratan teknis dengan matriks kebutuhan konsumen. Se lain matriks relasi, matriks lainnya yang disusun adalah matriks trade off. Matriks trade off disusun untuk mengetahui korelasi atau keterkaitan antar atribut yang terdapat pada matriks persayaratan teknis. 
3.12 Perhitungan Prioritas Pers yaratan Teknis, Kontibusi, se rta membuat Urutan Prioritas Pada tahap ini setiap atribut pada matriks persyaratan teknis akan dilakukan perhitungan nilai prioritasnya. Perhitungan prioritas dilakukan dengan menggunakan rumus 5. Setelah melakukan perhitungan prioritas, maka dilakukan perhitungan kotribusi dari setiap atribut matriks persyaratan teknis. Kontribusi merupakan persentase dari nilai prioritas setiap atribut, perhitungan dilakukan dengan menggunakan rumus 6. Setelah nilai prioritas dan kontibusi didapatkan, maka dilakukan pengurutan nilai prioritas maupun kontribusi dari nilai tertinggi hingga terendah. Pembuatan urutan prioritas ini dilakukan untuk mengetahui atribut mana yang perlu dikembangkan terlebih dahulu.

\subsection{Analis is Hasil Persyaratan Teknis}

Setelah terbentuk matriks HOQ, selanjutnya dilakukan analis is hasil Persyaratan teknis. Analisis dilakukan untuk mengetahui atribut kebutuhan konsumen yang penting untuk mesin pemutar adonan es. Analisis juga dilakukan untuk mengetahui persyaratan teknis apa yang menjadi prioritas utama, yang juga dapat digunakan untuk menyusun QFD fase kedua.

\section{Hasil dan Analisis}

Tahap awal metode QFD adalah mengidentifikasi apa yang dibutuhkan konsumen terhadap mesin pemutar adonan es. Identifikasi kebutuhan konsumen dilakukan dengan cara wawancara terhadap 5 UMKM produsen es puter. Data responden tersebut antara lain: Takim (52 tahun), Bagus (28 tahun), Ikhsan (54 tahun), Wandi (50 tahun), Arief (48 tahun). Data hasil wawancara tersebut selanjutnya disebut dengan atribut kebutuhan konsumen. Berdasarkan hasil wawancara didapatkan sebanyak sembilan atribut kebutuhan konsumen untuk mesin pemutar adonan es. Berikut merupakan atribut kebutuhan konsumen:

Tabel 2. Perhitungan Produktivitas

\begin{tabular}{|l|}
\hline \multicolumn{1}{|c|}{ Atribut Kebutuhan Kons umen } \\
\hline Mesin tidak mudah panas \\
\hline Kecepatan putaran mesin dapat diatur sesuai kebutuhan \\
\hline Dapat memutar 2 tabung sekaligus \\
\hline Mesin mudah dibersihkan \\
\hline Tabung es mudah dimasukkan dan dike luarkan dari mesin \\
\hline Mesin menggunakan material yang kuat dan kokoh \\
\hline Mesin mudah diperbaiki \\
\hline Mesin tidak makan tempat \\
\hline Mesin mudah dibuat \\
\hline
\end{tabular}

Analisis tingkat kepentingan konsumen (TKK) dilakukan untuk mengetahui atribut kebutuhan konsumen yang dirasa paling penting oleh konsumen. Analisis tingkat kepentingan konsumen dilakukan dengan cara pengisian kuisioner oleh responden. Berikut merupakan hasil perhitungan tingkat kepentingan konsumen untuk masing-masing atribut:

Tabel 3. Tingkat Kebutuhan Konsumen Mesin Pemutar Adonan Es

\begin{tabular}{|l|c|c|}
\hline \multicolumn{1}{|c|}{ Atribut Ke butuhan Kons umen } & $\left(\sum\right) \mathbf{x}$ & TKK \\
\hline Mesin tidak mudah panas & 22 & 4,4 \\
\hline Kecepatan putaran mesin dapat diatur sesuai kebutuhan & 22 & 4,4 \\
\hline Dapat memutar 2 tabung sekaligus & 21 & 4,2 \\
\hline Mesin mudah dibersihkan & 23 & 4,6 \\
\hline Tabung es mudah dimasukkan dan dike luarkan dari mes in & 22 & 4,4 \\
\hline Mesin menggunakan material yang kuat dan kokoh & 23 & 4,6 \\
\hline
\end{tabular}


JOURNAL OF INTEGRATED S YSTEM VOL 1. NO. 2, DESEMB ER 2018: 180-192

Tabel 3. Tingkat Kebutuhan Konsumen Mesin Pemutar Adonan Es (Lanjutan)

\begin{tabular}{|l|c|c|}
\hline \multicolumn{1}{|c|}{ Atribut Kebutuhan Kons umen } & $\left(\sum\right) \mathbf{x}$ & TKK \\
\hline Mesin mudah diperbaiki & 22 & 4,4 \\
\hline Mesin tidak makan tempat & 20 & 4 \\
\hline Mesin mudah dibuat & 21 & 4,2 \\
\hline
\end{tabular}

Analisis Tingkat Kepuasan Konsumen (TKP) dilakukan untuk mengetahui seberapa puas konsumen terhadap mesin pemutar es yang digunakan. Pada penelitian ini tidak dilakukan analisis tingkat kepuasan konsumen dikarenakan produk yang dianalis is masih belum diproduksi. Selain itu responden tidak menggunakan mesin pemutar es dalam proses produksi, sehingga responden masih belum bisa merasakan manfaat dari mesin pemutar adonan es.

Penentuan Target dilakukan dengan cara memilih nilai tertinggi antara TKK dan TKP. Pada penelitian ini nilai target didasarkan pada nilai TKK, dikarenakan tidak terdapat nilai TKP. Setelah menentukan nilai target, maka dapat dilakukan perhitungan rasio perbaikan. Rasio perbaikan (IR/Improvemnt Ratio) dilakukan untuk menilai apakah suatu atribut perlu dilakukan perbaikan atau tidak. Perhitungan rasio perbaikan dapat menggunakan rumus 2.7. Apabila nilai IR > 1, maka atribut tersebut perlu dilakukan perbaikan. Pada penelitian ini tidak digunakan TKP, melainkan menggunakan TKK. Perhitungan rasio perbaikan pada penelitian ini adalah nilai target dibagi nilai TKK. Nilai target pada penelitian kali ini bernilai sama dengan nilai TKK, sehingga nilai rasio perbaikan untuk semua atribut akan bernilai satu.

Tabel 4. Nilai Target dan Improvement Ratio

\begin{tabular}{|c|l|c|c|}
\hline No & \multicolumn{1}{|c|}{ Atribut Kebutuhan Kons umen } & Target & IR \\
\hline 1 & Mesin tidak mudah panas & 4,4 & 1 \\
\hline 2 & Kecepatan putaran mesin dapat diatur sesuai kebutuhan & 4,4 & 1 \\
\hline 3 & Dapat memutar 2 tabung sekaligus & 4,2 & 1 \\
\hline 4 & Mesin mudah dibersihkan & 4,6 & 1 \\
\hline 5 & Tabung es mudah dimasukkan dan dikeluarkan dari mesin & 4,4 & 1 \\
\hline 6 & Mesin menggunakan material yang kuat dan kokoh & 4,6 & 1 \\
\hline 7 & Mesin mudah diperbaiki & 4,4 & 1 \\
\hline 8 & Dimensi yang sesuai, sehingga tidak membutuhkan tempat yang luas & 4 & 1 \\
\hline 9 & Desain mesin sederhana dan Mudah dibuat & 4,2 & 1 \\
\hline
\end{tabular}

Penentuan poin penjualan dilakukan untuk mengetahui pengaruh masing-masing atribut kebutuhan konsumen terhadap minat konsumen untuk membeli produk. Produk yang dimaksud adalah mesin pemutar adonan es. Penilaian poin penjualan dilakukan dengan cara pengisian kuisioner oleh responden, yakni 5 UMKM produsen es puter. Semakin tinggi nilai poin penjualan suatu atribut, maka dapat dikatakan bahwa atribut tersebutlah yang sangat mempengaruhi minat konsumen untuk membeli produk. Berikut merupakan nilai poin penjualan yang didapatkan:

Tabel 5. Po in Penjualan Mesin Pemutar Adonan Es

\begin{tabular}{|l|c|}
\hline \multicolumn{1}{|c|}{ Atribut Kebutuhan Konsumen } & Poin penjualan \\
\hline Mesin tidak mudah panas & 1,38 \\
\hline Kecepatan putaran mesin dapat diatur sesuai kebutuhan & 1,38 \\
\hline Dapat memutar 2 tabung sekaligus & 1,44 \\
\hline Mesin mudah dibersihkan & 1,2 \\
\hline Tabung es mudah dimasukkan dan dike luarkan dari mesin & 1,32 \\
\hline
\end{tabular}


PENENTUAN PERS YARATAN TEKNIK DARI MES IN PEMUTAR ADONAN ES (Abi yyu S., dkk)

Tabel 5. Poin Penjualan Mesin Pemutar Adonan Es (Lanjutan)

\begin{tabular}{|l|c|}
\hline \multicolumn{1}{|c|}{ Atribut Kebutuhan Konsumen } & Poin penjualan \\
\hline Mesin menggunakan material yang kuat dan kokoh & 1,44 \\
\hline Mesin mudah diperbaiki & 1,32 \\
\hline Mesin tidak makan tempat & 1,22 \\
\hline Mesin mudah dibuat & 1,32 \\
\hline
\end{tabular}

Perhitungan raw weight merupakan perhitungan bobot dari masing-masing atribut kebutuhan konsumen. Perhitungan raw weight dapat dilakukan setelah melakukan analis is tingkat kepentingan konsumen, rasio perbaikan, serta perhitungan poin penjualan. Setelah melakukan perhitungan raw weight, maka dapat dilakukan perhitungan normalize raw weight. Perhitungan normalize raw weight adalah persentase bobot masing-masing atribut kebutuhan konsumen dari total keseluruhan bobot atribut kebutuhan konsumen. Berikut merupakan hasil perhitungan raw weight dan normalize raw weight yang didapatkan:

Tabel 6. Perhitungan raw weight dan normalize raw weight

\begin{tabular}{|c|c|c|c|}
\hline No & Atribut Kebutuhan Konsumen & $\begin{array}{c}\text { Raw } \\
\text { Weight }\end{array}$ & Normalize \\
\hline 1 & Mesin tidak mudah panas & 6,072 & 0,116 \\
\hline 2 & Kecepatan putaran mesin dapat diatur sesuai kebutuhan & 6,072 & 0,116 \\
\hline 3 & Dapat memutar 2 tabung sekaligus & 6,048 & 0,115 \\
\hline 4 & Mesin mudah dibersihkan & 5,52 & 0,105 \\
\hline 5 & Tabung es mudah dimasukkan dan dike luarkan dari mes in & 5,808 & 0,111 \\
\hline 6 & Mesin menggunakan material yang kuat dan kokoh & 6,624 & 0,126 \\
\hline 7 & Mesin mudah diperbaiki & 5,808 & 0,111 \\
\hline 8 & Dimensi yang sesuai, sehingga tidak membutuhkan tempat yang luas & 4,88 & 0,093 \\
\hline 9 & Desain mesin sederhana dan Mudah dibuat & 5,544 & 0,106 \\
\hline
\end{tabular}

Persyaratan teknik merupakan penerjemahan kebutuhan konsumen kedalam bahasa teknik dari produk. Penyusunan persyaratan teknis dilakukan dengan wawancara dan diskusi dengan narasumber ahli. Berikut merupakan atribut persyaratan teknis yang didapatkan dari hasil wawancara dan diskusi:

Tabel 7. Atribut Persyaratan Teknik Mesin Pemutar Adonan Es

\begin{tabular}{|l|}
\hline \multicolumn{1}{|c|}{ Atribut Persyaratan Teknik } \\
\hline Mesin Listrik \\
\hline Kecepatan Putaran \\
\hline Diameter pulley \\
\hline Belt pemutar \\
\hline Desain modular \\
\hline Alas mesin \\
\hline Jenis material \\
\hline Jenis pengunci \\
\hline Dimensi mesin \\
\hline Bentuk rangka mesin \\
\hline
\end{tabular}


JOURNAL OF INTEGRATED S YSTEM VOL 1. NO. 2, DES EMB ER 2018: 180-192

Selanjutnya dilakukan penyusunan matriks korelasi, matriks trade-off, serta penentuan prioritas, kontribusim dan urutan prioritas. Penyusunan matriks korelasi bertujuan untuk mencari hubungan antara matriks persyaratan teknik dengan atribut kebutuhan konsumen. Sedangkan penyusunan matriks trade off bertujuan untuk mencari hubungan antar atribut yang terdapat di matriks persyaratan teknik. Hubungan pada matriks korelasi maupun matriks trade-off didefinisikan dalam bentuk simbol ataupun angka, sesuai tabel 1.

Prioritas persyaratan teknik menunjukkan tingkat kepentingan dari suatu atribut persyaratan teknik untuk dikembangkan. Semakin tinggi nilai prioritas suatu atribut, maka atribut tersebut lebih diutamakan untuk dikembangkan lebih lanjut. Kontribusi merupakan persentase masing-masing atribut terhadap total keseluruhan nilai prioritas persyaratan teknik. Data yang didapatkan dari awal yakni atribut kebutuhan konsumen hingga penentuan nilai prioritas persyaratan teknik dan kontribusi digabungkan menjadi satu, sehingga menjadi matriks HOQ. Matriks HOQ dapat dilihat pada gambar. 
PENENTUAN PERS YARATAN TEKNIK DARI MES IN PEMUTAR ADONAN ES (Abiyyu S., dkk)

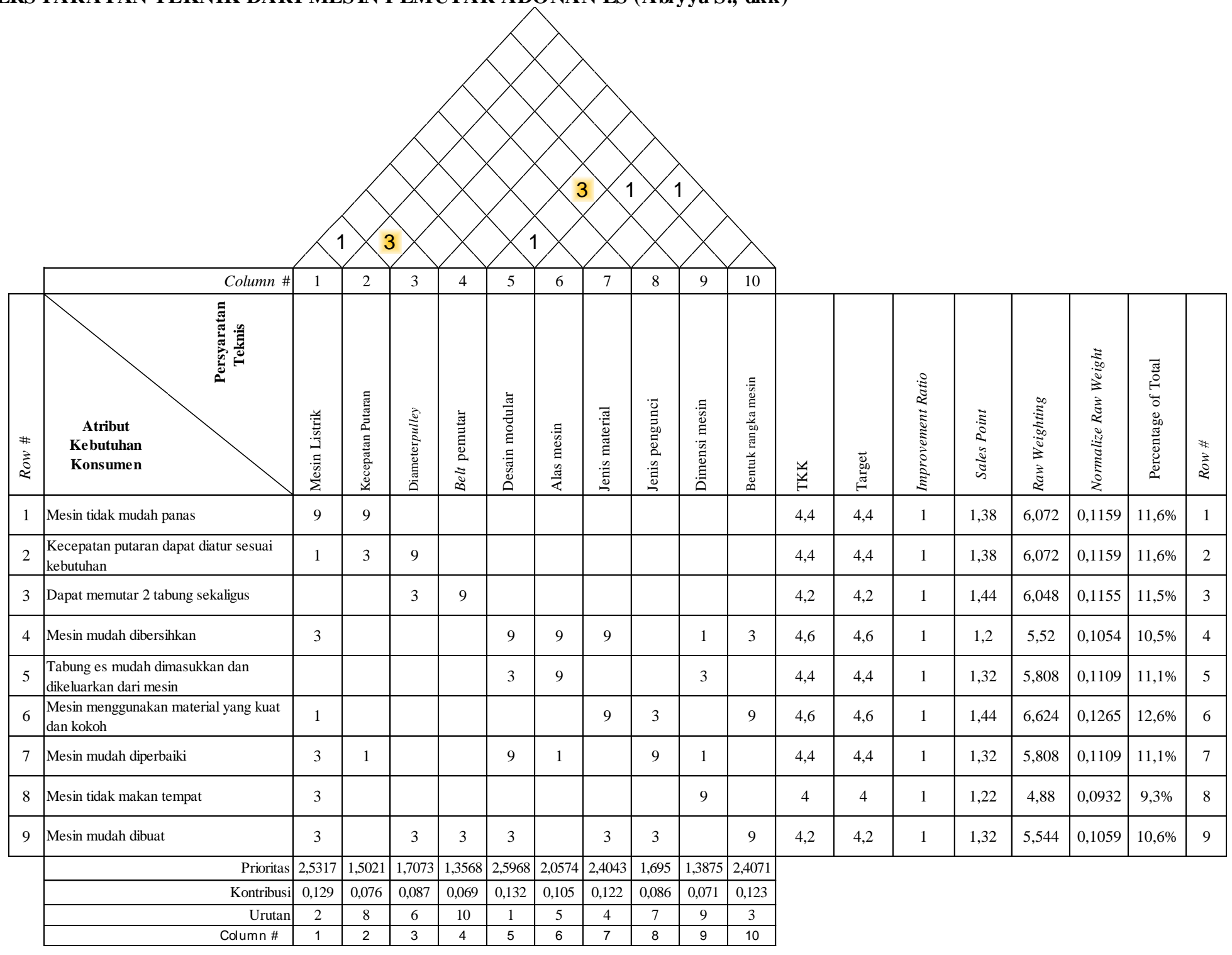

Gambar 4. Matriks HOQ Mesin Pemutar Adonan Es 
Produk mesin pemutar adonan es memiliki sembilan atribut kebutuhan konsumen yang didapatkan dari hasil wawancara. Atribut tersebut kemudian dicari tingkat kepentingannya dengan cara melakukan analisis tingkat kepentingan konsumen. Berdasarkan hasil analis is tingkat kepentingan konsumen (TKK) terdapat dua atribut yang memiliki nilai tertinggi tingkat kepentingannya, yakni: mesin mudah dibersihkan, serta mesin menggunakan material yang kuat dan kokoh. Kedua atribut ini dianggap hal yang terpenting bagi konsumen. Berdasakan hasil penentuan poin penjualan, semua atribut kecuali atribut mesin mudah dibersihkan, dapat dikatakan menarik minat konsumen untuk membeli produk. Hal tersebut dikarenakan nilai poin penjualan atribut tersebut lebih dari 1,2.

Penerjemahan atribut kebutuhan konsumen menjadi bahasa teknik dari produk dilakukan dengan cara wawancara dan diskusi bersama narasumber ahli. Berdasarakan hasil wawancara dan diskusi didapatkan sepuluh atribut persayaratan teknik produk. Seluruh atribut persyaratan teknik selanjutnya dicari nilai hubungannya dengan atribut kebutuhan konsumen saat menyusun matriks korelasi. Nilai hubungan tersebut digunakan dalam menentukan prioritas bersaman dengan nilai normalize raw weight. Penentuan prioritas dilakukan untuk menentukan atribut persyaratan teknik manakah yang diutamakan untuk dikembangkan. Berdasarkan hasil perhitungan, terdapat lima atribut yang memiliki nilai prioritas tertinggi. Atribut tersebut antara lain: desain modular, Mesin Listrik, Bentuk rangka mesin, jenis material, serta alas mesin.

\section{Kesimpulan}

Penyusunan QFD fase pertama atau matriks HOQ (House of Quality) didapatkan sembilan atribut kebutuhan konsumen. Atribut kebutuhan konsumen yang didapatkan antara lain: mesin tidak mudah panas, kecepatan putaran dapat diatur sesuai kebutuhan, dapat memutar 2 tabung sekaligus, mesin mudah dibersihkan, tabung es mudah dimasukkan dan dikeluarkan dari mesin, mesin menggunakan material yang kuat dan kokoh, mesin mudah diperbaiki, mesin tidak makan tempat, dan mesin mudah dibuat. Berdasarkan diskusi dengan narasumber ahli, didapatkan sepuluh atribut persyaratan teknik. Atribut persyaratan teknik tersebut antara lain: mes in listrik, kecepatan putaran, diameter pulley, belt pemutar, desain modular, alas mesin, jenis material, jenis pengunci, dimensi mesin, serta bentuk rangka mesin.

\section{Daftar Pustaka}

Bernal, L., Dornberger, U., Suvelza, A., dan Byrners, T., (2009), Quality Function Deployment (QFD) for Service, Universitat Leipzig.

Cohen, L., (1995), Quality Function Deployment: How to Make QFD Work To You, AddisonWesley Publishing Company, Boston.

Gargione, A, L., (1999), Using Quality Function Deployment (QFD) in the Design Phase of an Apartment Construction Project, Proseding IGLC-7, California.

Halim, V., (2014), Perencanaan Produk Olahan Wortel Menggunakan Metode Quality Function Deployment (QFD), Skirpsi, Teknik Industri, Universitas Ma Chung, Malang.

Jaiswal, E.S., (2012), A Case Study on Quality Funtion Deployment (QFD), IOSR Journal of Mechanical and Civil Engineering, 3(6), hal. 27 - 35.

Pyzdek, T., (2003), The Six Sigma Handbook, McGraw-Hill.

Rahmatika, I., (2008), Penerapan Quality Funtion Deployment (QFD) untuk Mengetahui Tingkat Kepuasan Konsumen Produk Biskuit di PT. Arnott's Indonesia, Skripsi, Fakultas Teknologi Pertanian, Institut Pertanian Bogor, Bogor.

Van de Poel, I., (2007), Methodological Problems in QFD and Directions for Future Development, Res Eng Design, Vol. 18, Hal. 21-36. 